\title{
Performance Measures: An Application of Economic Value Added
}

\author{
Nikhil Chandra Shil, ACMA \\ Department of Business Administration \\ East West University \\ 43, Mohakhali C/A, Dhaka - 1212, Bangladesh \\ Tel: 9887-989 ext 253 E-mail: nikhilacc@yahoo.com
}

\begin{abstract}
Economic Value Added (EVA) is a value based performance measure that gives importance on value creation by the management for the owners. Profit maximization as a concept is age-old, wealth maximization is matured and value maximization is today's wisdom. Stern Stewart's EVA raises storm in corporate world and gives a new way to think about rewarding management. Usability of $E V A$ largely depends on the quality of accounting information system, as traditional information system will not provide sufficient information to compute true EVA. Thus, EVA is required to be tailored in line with accounting system, management philosophy and the degree of demand of such a system. In this paper, an earnest effort has been made to explain theoretical foundation of $E V A$ with its origination, definition, ways to make it tailored, adjustments required, scope and some other related issues. The methodology used is a type of theoretical mining of logics resulting a step-by-step process required for $E V A$ implementation. As corporate house plans to move from traditional to value based performance measures, EVA would yield good result and the paper may become helpful to them to comprehend the methodology.
\end{abstract}

Keywords: Value Based Performance Measure, Tailored EVA, Residual Income $(R I)$, Accounting Distortions, Shareholders' Value, Value Based Measure, Market Value Added, True EVA

\section{Introduction}

Economic Value Added $(E V A)$ is the financial performance measure that comes closer than any other to capturing the true economic profit of an enterprise. Thus, in modern economics and finance area, EVA holds an important part that has less debate among practitioners. It is the performance measure most directly linked to the creation of shareholders wealth over time. Shareholders are very much choosy for their interest into the business and they like management to come up with very specific solution. By the time, it is established that the very logic of using EVA is to maximize the value for the shareholders. More explicitly, EVA measure gives importance on how much economic value is added for the shareholders by the management for which they have been entrusted with. EVA is exceptional from other traditional tools in the sense that all other tools mostly depend on information generated by accounting. And we know, accounting, more often produces historical data or distorted data that may have no relation with the real status of the company. But, EVA goes for adjustments to accounting data to make it economically viable.

Under conventional accounting, most companies appear profitable but many in fact are not. As Peter Drucker put the matter in a Harvard Business Review article, "Until a business returns a profit that is greater than its cost of capital, it operates at a loss. Never mind that it pays taxes as if it had a genuine profit. The enterprise still returns less to the economy than it devours in resources...until then it does not create wealth; it destroys it." Company may intentionally pay tax to prove that they have made profit for their shareholders and thus a falsification is done with owners that is not a rare corporate practice. $E V A$ corrects this error by explicitly recognizing that when managers employ capital they must pay for it, as if it were a wage. It also adjusts all distortions that are very much prevalent in the information generated by conventional accounting. Thus, it is the most demanded tool for the owners in every situation. It has been implemented in numerous large companies to motivate managers to create shareholder value (Dodd and Chen, 1996). The decision role is very simple; if the EVA is positive, the company creates shareholder wealth. Negative EVA indicates that shareholder wealth is destroyed (Stewart, 1991). De facto, EVA is the same as residual income $(R I)$ that has been in existence for several decades. The only significant difference between the two lies in the handling of accounting distortions (Dodd and Chen, 1997). EVA removes existing distortions by using up to 164 adjustments to 
traditional accounting data (Stewart, 1991; Blair, 1997). These distortions are disregarded in the RI calculation. In this paper, an earnest effort has made to introduce $E V A$ as a value based performance measurement tool. Thus the paper targets the readers who have no previous idea on the technicality of EVA. An all-out effort is deployed to make it all-inclusive theoretically so that it can be used as a manual or guideline for implementing EVA for the first time. At first, EVA is defined with historical backgrounds. Later on, some steps are identified to simplify the EVA implementation process. Finally, advantages of using EVA are discussed with reference to other performance measurement tool. Scope of $E V A$ is also defined with references to various research interests to give a tool a particular shape.

\section{Historical background}

EVA is not a new discovery. An accounting performance measure called residual income is defined to be operating profit subtracted with capital charge. EVA is thus one variation of residual income with adjustments to how one calculates income and capital. According to Wallace (1997, p.1) one of the earliest to mention the residual income concept was Alfred Marshall in 1890. Marshall defined economic profit as total net gains less the interest on invested capital at the current rate. According to Dodd \& Chen $(1996$, p. 27) the idea of residual income appeared first in accounting theory literature early in this century by e.g. Church in 1917 and by Scovell in 1924 and appeared in management accounting literature in the 1960s. Also Finnish academics and financial press discussed the concept as early as in the 1970s. It was defined as a good way to complement ROI-control (Virtanen, 1975, p.111). In the 1970s or earlier residual income did not got wide publicity and it did not end up to be the prime performance measure in great deal of companies. However $E V A$, practically the same concept with a different name, has done it in the recent years. Furthermore the spreading of EVA and other residual income measures does not look to be on a weakening trend. On the contrary the number of companies adopting EVA is increasing rapidly (Nuelle, 1996, p. 39; Wallace, 1997, p. 24 and Economist 1997/2). We can only guess why residual income did never gain a popularity of this scale. One of the possible reasons is that Economic value added (EVA) was marketed with a concept of Market value added $(M V A)$ and it did offer a theoretically sound link to market valuations.

The origins of the value added concepts date all the way back to the early 1900's (Bromwich \& Walker, 1998, p. 392). Stern Stewart \& Co trademarks EVA in 1990's when the tool is introduced and subsequently adopted by several major corporations that lead $E V A$ to have successful stories at the very beginning. Mainly professional literature mostly aimed at presenting, promoting or discussing the EVA concepts in relation to consulting work. While most of this, partly anecdotal, literature looks at the advantages of the concept with a few critical views also. Subsequent sources are too numerous for an extensive listing, but for instance there is material such as Milunovich \& Tsuei (1996), Anctil, Jordan \& Mukherji (1998), Damodaran (1999), Mouritsen (1998), Bowen \& Wallace (1999), and Dodd \& Johns (1999). There also is much WWW based material such as Mäkelä (1998), Weissenrieder (1999), and Stern Stewart \& Co. (2000).

Empirical research literature measuring the strength of the relation between market returns (or market value) and EVA compared to the relation between market returns and the traditional income measures. O'Byrne (1996, p.125) concludes, "EVA, unlike NOPAT [net operating profit after taxes] or other earnings measures like net income or earnings per share, is systematically linked to market value. It should provide a better predictor of market value than other measures of operating performance." Also Uyemura, Kantor \& Pettit (1996) arrive at similar conclusions. Stark \& Thomas (1998, p. 445) provide "some support for the advocates of the use of $R I$ for planning and control" from the market relation. However, Biddle, Bowen \& Wallace (1997) find "little evidence to support the Stern Stewart claim that EVA is superior to earnings in its association with stock return or firm values". Chen \& Dodd (1997) conclude that EVA measures provide relatively more information than the traditional measures of accounting in terms of the stock return association, but that EVA should not entirely replace the traditional measures since measures such as $E / P, R O A$ and $R O E$ have incremental value in monitoring firm performance. They also observe that there is no significant difference between $E V A$ and the traditional $R I$ in terms of the association with stock returns.

Some literature EVAluates $E V A$ as a management tool from the point of view of the accounting measurement. O'Hanlon \& Peasnell (1998) thoroughly discuss EVA as a value-based performance indicator, Stern Stewart Co intricate adjustments, EVA benchmarks, and EVA-based bonuses. Bromwich \& Walker (1998) add to the theoretical discussion by pondering the EVA debate all the way from Hicksian income concepts. Pfeiffer (2000) considers mathematically $E V A$ vs. discounted cash flow methods for resolving internal agency problems in decentralized decision-making. Besides the theoretical discussion, understanding is needed about the numerical behavior of the EVA under different conditions and about EVA's numerical relationship to the accounting measures like Return on Investments (ROI), Return on Equity $(R O E)$ and to economic profitability measures like the Internal Rate of Return (IRR).

\section{EVA Definition}

EVA is the amount of economic value added for the owners by management. The thrust area for today's management is to find means to create value for the owners. It is now established that the accounting profit in no cases represents the 
real value created for the owners. But, it may originate the calculation. In other words, accounting profit is required to be converted into economic profit. Under $E V A$, all distortions in conventional accounting are identified and accounting profit is adjusted to make it distortion free and finally we get the amount of $E V A$. Stewart defined EVA (1990, p.137) as Net operating profit after taxes (NOPAT) subtracted with a capital charge. Algebraically, it can be stated as follows:

$$
\begin{aligned}
& \text { EVA }=\text { NOPAT }- \text { Capital Costs } \\
& \Rightarrow \text { NOP }(1-T)-\text { Capital Employed } \times \text { Cost of Capital } \\
& \Rightarrow \text { Adjusted NOP }(1-T)-\text { Capital Employed } \times W A C C \\
& \Rightarrow \text { Adjusted NOP }(1-T)-\left[\text { Capital Employed } \times\left\{\left(R_{e} \times \frac{E}{C E}\right)+\left(R_{d} \times \frac{D}{C E}\right)(1-T)+\cdots\right\}\right] \\
& \Rightarrow \text { Re turn - Capital Employed } \times W A C C \\
& \Rightarrow \text { (Rate of ROI - WACC ) Capital Employed }
\end{aligned}
$$

From the above derivation it is clear that EVA computation requires a lot of hurdles to be passed. Net operating profit is adjusted for accounting distortions and a charge on capital employed at the rate of weighted average cost of capital (WACC) is subtracted from NOPAT to reach to the amount of EVA. It aims to tell about what happens to the wealth of shareholders. As per equation 1, earning a return greater than the cost of capital increases value for the owners and vice versa. For listed companies Stewart defined another measure that assesses if the company has created shareholder value. If the total market value of a company is more than the amount of capital invested in it, the company has managed to create shareholder value. If the case is opposite, i.e., the market value is less than the amount of capital invested; the company has destroyed shareholder value. Stewart (1990, p.153) calls it as Market Value Added (MVA) and can be equated as follows:

$$
\begin{aligned}
& M V A=\text { Market Value of the Company - Capital Invested } \\
& \Rightarrow \text { Market Value of Equity - Book Value of Equity (assu min g, Capital invested = BV of Equity) } \\
& \Rightarrow(M V-B V) \text { No. of shares outs tan ding } \\
& \Rightarrow \text { Present Value of All Future EVA } \\
& \text { In other words, } \\
& \text { Market Value of Equity = Book VAlue of Equity + Pr esent Value of All Future EVA ...........(eq.3) }
\end{aligned}
$$

$M V A$ is identical by meaning with the market-to-book ratio. The difference is only that $M V A$ is an absolute measure and market-to-book ratio is a relative measure. If $M V A$ is positive that means that market-to-book ratio is more than one. Negative $M V A$ means market-to-book ratio less than one. If a company's rate of return exceeds its cost of capital, the company will sell on the stock markets with premium compared to the original capital (has positive $M V A$ ). On the other hand, companies that have rate of return smaller than their cost of capital sell with discount compared to the original capital invested in company. Whether a company has positive or negative $M V A$ depends on the level of rate of return compared to the cost of capital. All this applies to $E V A$ also. Thus positive $E V A$ means also positive $M V A$ and vice versa. But, $M V A$ is not a performance metric like $E V A$, rather it is a wealth metric, measuring the level of value a company has accumulated over time.

The implementation process of EVA parallels the successful implementation of Stern Stewart 4Ms, e.g., measurement, management system, motivation and mindset. $E V A$ at the very beginning looks for a measurement base for converting accounting profits into economic reality. Without commitment from management, the implementation of EVA is impossible. Management system should be streamlined with the basic EVA philosophy. It should be guaranteed that the application of $E V A$ is well accepted by all. And finally, mindset should be cultivated into the corporate culture to make it the focal point for reporting, planning and decision-making.

\section{4. $E V A$ as a Management Tool}

$E V A$ is superior to accounting profits as a measure of value creation because it recognizes the cost of capital and, hence, the riskiness of a firm's operations (Lehn \& Makhija, 1996, p.34). It is used as a value based performance measure tool more widely. In this context, EVA is compared with some traditional measures and with some other value based measures as well.

\subsection{EVA vs. Traditional Measures}

$E V A$ is based on the common accounting based items like interest bearing debt, equity capital and net operating profit. It differs from the traditional measures mainly by including the cost of equity. Salomon and Laya (1967) studied the accounting rate of return $(A R R)$ and the extent to which it approximates the true return measured with $I R R$. Harcourt (1965), Solomon and Laya (1967), Livingston and Solomon (1970), Fischer and McGowan (1983) and Fisher (1984) 
concluded that the difference between accounting rate of return $(A R R)$ and the true rate of return is so large that the former cannot be used as an indication of the later (De Villiers, 1997, pp. 286-87).

Among all traditional measures, return on capital is very common and relatively good performance measure. Different companies calculate this return with different formulas and call it also with different names like return on investment $(R O I)$, return on invested capital $(R O I C)$, return on capital employed (ROCE), return on net assets (RONA), return on assets $(R O A)$ etc. The main shortcoming with all these rates of return is in all cases that maximizing rate of return does not necessarily maximize the return for shareholders. Observing rate of return and making decisions based on it alone is similar to assessing products on the "gross margin on sales" -percentage. The product with the highest "gross margin on sales" percentage is not necessary the most profitable product. The difference between $E V A$ and $R O I$ is actually exactly the same as with $N P V$ (Net present value) and IRR (Internal rate of return). IRR is a good way to assess investment possibilities, but we ought not to prefer one investment project to the other on the basis of IRR only.

Mathematically EVA gives exactly the same results in valuations as Discounted Cash Flow $(D C F)$ or Net Present Value (NPV) (Stewart, 1990, p. 3; Kappi, 1996), which are long since widely acknowledged as theoretically best analysis tools from the stockholders' perspective (Brealey \& Mayers, 1991, pp. 73-75). In the corporate control, it is worth remembering that $E V A$ and $N P V$ go hand in hand as also ROI and $I R R$. The formers tell us the impacts to shareholders wealth and the latters tell us the rate of return. There is no reason to abandon $R O I$ and $I R R$. They are very good and illustrative measures that tell us about the rate of returns. IRR can always be used along with $N P V$ in investment calculations and $R O I$ can always be used along with $E V A$ in company performance. However, we should never aim to maximize $I R R$ and $R O I$ and we should never base decisions on these two metrics. $I R R$ and $R O I$ provide us additional information, although all decisions could be done without them. Maximizing rate of returns (IRR, ROI) does not matter, when the goal is to maximize the returns to shareholders. EVA and $N P V$ should be in the commanding role in corporate control and $R O I \& I R R$ should have the role of giving additional information.

\subsection{EVA vs. Other Value-based Measures}

$E V A$ is not the only value-based measure rather we have a good number of tools that are also used for the same. Some are developed by consulting industries and others are by academics. Consultants like to use their particular acronym to establish it as their personal brand though it would not differ very much of the competitors' measures. Thus the range of these different acronyms is wide. Some of such measures are mentioned here in a tabular format so that readers can grasp them easily.

\section{Insert Table 1 here}

Many of these shareholder value measures are based more on cash flows that make them more effective than $E V A$. On the other hand, these other measures are quite complicated to calculate and based on more subjective data than EVA. At least CFROI and CVA defer most of the depreciation into later years in order to achieve smooth return or smooth capital costs. EVA is the most widely used Value-Based performance measure (Myers, 1996, p.42) probably just because it happens to be an easier concept compared to the others. In implementing $E V A$, one of the most important things is to get the people in organizations to commit to EVA and thereby also to understand EVA (Klinkerman, 1997).

\section{Steps in EVA Computation}

EVA computation requires some basis steps. The common steps are exemplified here that may be modified due to the typical nature of business or processes where it has been used.

\section{Step 1: Collect and Review Financial Statements}

EVA is based on the financial data produced by traditional accounting system. Most of the data come from either income statement or balance sheet both of which are available from general-purpose financial statements.

\section{Step 2: Identify the distortions and adjustments required to make it distortion free}

Stern Stewart has identified around 164 potential adjustments to GAAP and to internal accounting treatments, all of which can improve the measure of operating profits and capital. As financial statements are mendatorily prepared under $G A A P$, distortions will be there and identification of distortions is an art that requires a sound understanding of $E V A$ technicalities to identify and to adjust them as well. Now the question comes, to what extent it can be adjusted. Let's have a look at the following EVA spectrum.

\section{Insert Figure 1}

The "Basic $E V A$ " is the unadjusted $E V A$ quoted from the GAAP operating profits and balance sheet. "Disclosed $E V A$ " is used by Stern Stewart in its published $M V A / E V A$ ranking and computed after a dozen standard adjustments to publicly available accounting data. "True EVA", at the extreme right is the accurate EVA after considering all relEVAnt adjustments to accounting data. But our interest is at the "Tailored $E V A$ ". Each and every company must develop their tailored $E V A$ definition, peculiar to its organizational structure, business mix, strategy and accounting policies - one that 
optimally balances the trade-off between the simplicity and precision. Once the formula is set, it should be virtually immutable, serving as a sort of constitutional definition of performance.

\section{Step 3: Identify the company's capital structure (CS)}

A company's capital structure (CS) comprises all of the money invested in the company either by the owner or by borrowing from outsiders formally. It is the proportions of debt instruments and preferred and common stock on a company's balance sheet (Van Horne, 2002). Stewart (1990) defined capital to be total assets subtracted with non-interest bearing liabilities in the beginning of the period. However, it can be computed under anyone of the following methods:

Direct Method: By adding all interest bearing debts (both short and long term) to owner's equity.

Indirect Method: By subtracting all non-interest bearing liabilities from total liabilities (or total assets).

\section{Step 4: Determine the company's weighted average cost of capital (WACC)}

Estimation of cost of capital is a great challenge so far as EVA calculation for a company is concerned. The cost of capital depends primarily on the use of the funds, not the source (Ross et. al., 2003). It depends on so many other factors like financial structures, business risks, current interest level, investors expectation, macro economic variables, volatility of incomes and so on. It is the minimum acceptable rate of return on new investment made by the firm from the viewpoint of creditors and investors in the firms' securities (Schall \& Haley, 1980). Some financial management tools are available in this case to calculate the cost of capital. A more common and simple method is Weighted Average Cost of Capital (WACC) (Copeland et. al., 1996).

For calculating $W A C C$, we have to know a lot of other issues like

1) Components of capital employed like equity, debt etc;

2) Respective weight of various components into total amount of capital employed;

3) Factors that affect the risk and return of various components in a capital structure;

4) Standalone cost of all such components in a capital structure.

The overall cost of capital is the weighted average of the costs of the various components of the capital structure. The cost of each component of the firm's capital - debt, preferred stock, or common stock equity - is the return that investors must forgo if they are to invest in the firm's securities (Kolb \& DeMong, 1988). The Capital Asset Pricing Model $(C A P M)$ is a common method in estimating the cost of equity (Copeland et. al., 1996). The CAPM is stated in equation 4.

$R_{E}=R_{f}+\beta\left(R_{M}-R_{f}\right)$

Thus, CAPM postulates that the cost of equity $\left(R_{e}\right)$ is equal to the return on risk-free security $\left(R_{f}\right)$ plus a company's systematic risk, called beta $(\beta)$, multiplied by the market risk premium $\left(R_{M}-R_{f}\right)$ (Copeland et. al., 1996). Risk premium is associated with the specific risks of a given investment (Block \& Hirt, 2002). For large U.S. companies, the recommended market risk premium is 5 to 6 percent (Copeland et. al., 1996; Stewart, 1991). For publicly traded small companies, the market risk premium is significantly higher with values around 14 percent (Ross et. al., 1999). In our environment, market risk is so volatile that the appropriate premium, demanded by the owners against their investment, for even the large companies cannot be accurately estimated. Even no company takes the responsibility to work in this area. Thus, the use of CAPM is not impossible but difficult. Dividend discount model is another popular model in this case where market price of a share is equal to the present value of future streams of dividends (Khan and Jain, 1999). The model is given in equation 5 that can be solved for cost of equity if market price per share $(P)$, earnings per share $(E)$, retention ratio $(b)$ and growth rate $(g)$ is known.

Calculating cost of other components in a capital structure is quite simple and in most of the cases publicly available. We can fit all information into the following equation (6) to compute WACC provided that standalone cost for each component (common equity - ce, preferred equity - pe, debt $-d$, others $-x$ ), respective weights $(W)$ and corporate tax rate $\left(T_{c}\right)$ is available:

$W A C C=\left(R_{c e} \times W_{c e}\right)+\left(R_{p e} \times W_{p e}\right)+\left(R_{d} \times W_{d}\right)\left(1-T_{c}\right)+\left(R_{x} \times W_{x}\right)$.

\section{Step 5: Calculate the company's Net Operating Profit after Tax (NOPAT)}

NOPAT (eq. 7) is a measure of a company's cash generation capability from recurring business activities and disregarding its capital structure (Dierks and Patel, 1997). NOPAT is derived from NOP simply by subtracting calculated taxes from NOP $\left[N O P A T=N O P \times\left(1-T_{c}\right)\right]$. But adjustments should be made to the accounting profit to convert it into economic profit.

NOPAT = Net operating profit $-\{$ (Net operating profit ? excess dereciatio $\mathrm{n}$ ? other increase

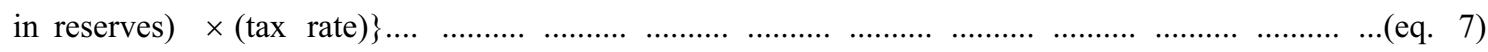




\section{Step 6: Calculation of Economic Value Added}

Finally, the $E V A$ can be calculated by subtracting capital charges from NOPAT (eq. 7) as shown in eq. 8 (Stewart, 1991 ; Reimann, 1988).

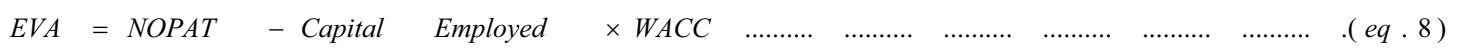

If the $E V A$ is positive, the company created value for its owner. If the $E V A$ is negative, owner's wealth gets reduced.

\section{Scope and Advantages of $E V A$}

$E V A$ as a management tool can be used in all managerial functions provided that it has been made tailored with the context. It has a strong relationship with share prices. As per eq. 3, the market value of a company is its book value plus the current value of future EVA. Stewart (1990, pp.215 - 218) has first studied this relationship with market data of 618 U.S. companies and presents the results in his book "The quest for value". Lehn and Makhija (1996) study EVA and $M V A$ as performance measures and signals for strategic change. Their data consists of 241 U.S. companies and cover years 1987, 1988, 1992 and 1993. However, Tero Telaranta (1997) has conducted a study about the correlation of EVA and share prices and concluded that $E V A$ is not any better than traditional performance measures.

$E V A$ based bonus plan produces positive results within an organization. Wallace (1997) studies the effects of adopting management bonus plans based on residual income measures. The study also suggests superior performance with the companies using EVA. Motivating bonus system normally encourages managers to exceed the normal performance level and even after the payment of the management's bonuses, the return to shareholders is more than it would have been without the bonus system. $E V A$ bonus systems are also good in decreasing agency problems. $E V A$ might also be suitable to uniting the interests of the management/owners and ordinary employees. According to professors Michael J. Jensen from Harvard Business School and Kevin J. Murphy from University of Chicago the biggest problem with top management salaries is that managers are currently paid like bureaucrats rather than like value maximizing entrepreneurs (Jensen \& Murphy 1990, p.1). They also state that traditional bonus systems produce far too small incentives for good performers and guarantee too big compensation for mediocre performers (1990, p.3). EVA can also be used in Group-level controlling of operations. EVA may also ensure optimum capital structure by making the firm properly levered. But, adopting $E V A$ simply as a performance measurement metric, in the absence of some ideas as to how you're going to create value, isn't going to get you anywhere (Kroll 1997, p.109). Thus, proper understanding is important to define its scope and to retrieve the maximum benefits out of it.

\section{Limitations of $\boldsymbol{E} \boldsymbol{V} \boldsymbol{A}$}

$E V A$ has a lot of advantages though it is not free of limitations. Some of the limitations are pointed out below:

1) $E V A$ is criticized to be a short-term performance measure. Some companies have concluded that $E V A$ does not suit them because of their focus on long-term investments. An example is offered by American company GATX (Glasser, 1996), which leases transportation equipment and makes fairly long-term investments.

2) The true return or true EVA of long-term investments cannot be measured objectively because future returns cannot be measured; they can only be subjectively estimated.

3) $E V A$ is probably not a suitable primary performance measure for companies that have invested heavily today and expect positive cash flow only in a distant future.

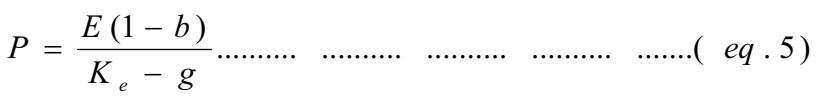

4) The periodic $E V A$ fails to estimate the value added to shareholders, because of the inflation and other factors.

5) $E V A$ suffers from wrong periodizing. A company may have a lot of undepreciated new assets in its balance sheet and it might show negative $E V A$ even if the business would be quite profitable in the long run.

6) Traditional financial ratios are commonly used for distress prediction. It was observed that $E V A$ does not have incremental value in the predicting.

\section{Conclusion}

During the 1990's value based management has made a strong entry in the assortment of management tools in the form of $E V A$ as marketed in particular by Stern Stewart \& Co. Since then, it has successfully taken an important place in corporate world and we have seen maximum utilization of it. The central idea of $E V A$ is subtracting the cost of capital from the firm's profits to measure, as the term indicates, the economic additional value produced by the firm to its owners over the weighted cost of the capital employed. It is well accepted from both side of the coin, i. e., owners and management. Owners are happy to see the amount of value added and management is happy to get reward proportionately. But, the challenge is to implement it for the first time. If the tool is not welcomed at the very beginning, 
it will produce nothing. Keeping EVA simple is also viewed as an important feature in successful implementation (Gressle, 1996).

$E V A$ has some inherent limitations also. Major limitations are generated due to the conventional accounting system that produces time-barred data. Thus, calculating true EVA becomes a challenge. But, we can make it tailored through EVA team, formed for successful implementation of the tool. The team will be responsible to find out all distortions and the way to adjust them to convert accounting profit into economic profit.

EVA has both advantages and limitations. Thus, using EVA only is no case a good decision. Rather, it should be used with other to take decisions more effectively. Companies may go for simulations over past several years' performance to find out the areas where EVA as a managerial tool is stronger over others. And where other tools show important correlations. Then, a set of tools can be used simultaneously in line with the philosophy of management.

\section{References}

Anctil, R. M., Jordan, J. S., \& Mukherji, A. (1998). Activity-based costing for Economic Value Added ${ }^{\circledR}$. Review of Accounting Studies, 2(3), 231-264.

Bacidore, J. M., Boquist, J. A., Milbourn, T.T., \& Thakor, A.V. (1997). The Search for the Best Financial Performance Measure. Financial Analysts Journal, 11-20.

Biddle, G. C., Bowen, R. M., \& Wallace, J. S. (1997). Does EVA beat earnings? Evidence on associations with stock returns and firm values. Journal of Accounting and Economics, 24(3), 301-336.

Blair, A. (1997). EVA Fever. Management Today, 42 - 45.

Blair, A. (1997). Watching the new metrics. Management Today, 48 - 50.

Block, S. B., \& Hirt, G. A. (2002). Foundations of Financial Management, McGraw-Hill Irwin.

Bowen, R. M., \& Wallace, J. S. (1999). Interior Systems, Inc. The decision to adopt EVA registered trademark. Accounting Education, 14(3), 517 - 541.

Brealey, R. A., \& Mayers, S. C. (1991). Principles of Corporate Finance, McGraw-Hill Series in Finance, McGraw-Hill, Inc. New York.

Bromwich, M., \& Walker, M. (1998). Residual income past and future. Management Accounting Research, 9(4), 391 419.

Chen, S., \& Dodd, J. L. (1997). Economic Value Added (EVA $\left.{ }^{\mathrm{TM}}\right)$ : An empirical examination of a new corporate performance measure. Journal of Managerial Issues, 9(3), 318 - 333.

Copeland, T., Koller, T., \& Murrin, J. (1996). Valuation: Managing and Measuring the Value of Companies, New York, NY: John Wiley and Sons, Inc.

Damodaran, A. (1998). Value creation and enhancement: back to the future. Contemporary Finance Digest, 2(4), 5 - 52.

De Villiers, J. (1997). The distortions of Economic Value Added. Journal of Economics and Business, 49(3), 285 - 300.

Dierks, P. A., \& Patel, A. (1997). What is EVA, and How Can It Help Your Company? Management Accounting, 79(5), $52-58$.

Dodd, J. L. \& Johns, J. (1999). EVA reconsidered. Business and Economic Review, 45(3), 13 - 18.

Dodd, J. L., \& Chen, S. (1996). EVA: A new panacea? Business and Economic Review, 42, 26-28.

Economist (1997). Valuing companies: A star to sail by. The Economist, 57 - 59.

Fisher, A. B. (1995). Creating Stockholder Wealth. Fortune, 132(12), 105-116.

Glasser, J. J. (1996). How EVA works against GATX. Chief Executive, 42 - 43.

Gressle, M. (1996). Abstract of "How to implement EVA and make share prices rise". Corporate cash flow, 17, 28 - 30.

Hoque, M., Akter, M., \& Shil, N. C. (2004). Value-based Measure: An Application of EVA in Small Manufacturing Company in Bangladesh. Journal of the Institute of Bankers Bangladesh, 51(2), 135-155.

Jensen, M. C., \& Murphy, K. J. (1990). CEO Incentives: Its Not How Much You Pay, But How? Harvard Business Review, $138-153$.

Kappi, J. (1996). Corporate valuation: A note. Unpublished working paper, Helsinki School of Economics and Business Administration, Helsinki.

Khan, M. Y., \& Jain, P. K. (1999). Financial Management: Text and Problems, Tata McGraw-Hill Publishing Company Limited, New Delhi.

Klinkerman, S. (1997). Cast study: EVA at Centura Banks. Banking strategies, 73(1), 58 - 59. 
Kolb, B. A., \& DeMong, R. F. (1988). Principles of Financial Management, Irwin.

Kroll, K. M. (1997). EVA and creating value. Industry week, 49, $102-109$.

Lehn, K., \& Makhija, A. K. (1996). EVA and MVA: As Performance Measures and Signals for Strategic Change. Strategy and Leadership, 34 - 38.

Mäkeläinen, E. (1998). Economic Value Added as a Management Tool.

[Online] Available: http://www.EVAnomics.com/EVAstudy/ EVAstudy.shtml. (Retrieved from January 20, 2000)

Milunovich, S., \& Tsuei, A. (1996). EVAO in the computer industry. Journal of Applied Corporate Finance, 9(1), 104 115.

Mouritsen, J. (1998). Driving growth: Economic Value Added versus Intellectual Capital. Management Accounting Research, 9(4), 461 - 482.

Myers, R. (1996). Metric wars. CFO, 12, 41 - 50.

Nuelle, F. (1996). The two faces of EVA. Chief executive, 39.

O'Byrne, S. F. (1996). EVA and market value. Journal of Applied Corporate Finance, 9(1), 116 - 125.

O'Hanlon, J., \& Peasnell, K. (1998). Wall Street's contribution to management accounting: the Stern Stewart $E V A^{\circledR}$ financial management system. Management Accounting Research, 9(4), 421 - 444.

Ottoson, E., \& Weissenrieder, F. (1996). Cash Value Added - a new method for measuring financial performance. Gothenburg Studies in Financial Economics, No. 1. [Online] Available: http://www.anelda.com/ (Retrieved from April 10, 1999)

Pfeiffer, T. (2000). Good and bad news for the implementation of shareholder-value concepts in decentralized organizations: A critical study comparing the DCF method and the EVA method. Schmalenbach Business Review, 52(1), $68-91$.

Rappaport, A. (1986). Creating shareholder value: The new standard for business performance. New York. The Free Press, A Division of Macmillan Publishers.

Reimann, B. C. (1988). Managing for the Stockholder: An Overview of Value-Based Planning. Planning Review, 16(1), $10-22$.

Ross, S. A., Westerfield, R. W., \& Jaffe, J. (1999). Corporate Finance, Irwin McGraw-Hill.

Ross, S. A., Westerfield, R. W., \& Jordan, B. D. (2003). Fundamentals of Corporate Finance, Tata McGraw-Hill Publishing Company Ltd.

Schall, L. D., \& Haley, C. W. (1980). Introduction to Financial Management, McGraw-Hill Book Company.

Stark, A.W., \& Thomas, H. M. (1998). On the empirical relationship between market value and residual income in the U.K. Management Accounting Research, 9(4), 445 - 460.

Stern Stewart \& Co. (2000). WWW home page. [Online] Available: http://www.sternstewart.com/index2.shtml. (Retrieved from January 20, 2000)

Stewart, G. B. (1990). The Quest for Value: the EVA management guide, Harper Business, New York.

Stewart, G. B. (1991). The Quest for Value: A Guide for Senior Managers, Harper Business, New York.

Telaranta, T. (1997). On residual income variables and shareholder wealth creation. Master's Thesis. Helsinki School of Economics and Business Administration. Helsinki 1997.

Uyemura, D. G., Kantor, C. C., \& Pettit, J. M. (1996). EVA $A^{\circledR}$ for banks: Value creation, risk management, and profitability measurement. Journal of Applied Corporate Finance, 9(2), 94 - 113.

Van Horne, J. C. (2002). Financial Management and Policy, Pearson Education Asia.

Virtanen, K. (1975). Pääoman tuottoasteen hyväksikäyttömahdollisuudet.. Tehokas yritys. 97 - 113

Wallace, J. S. (1997). Adopting residual income-based compensation plans: Evidence of effects on management actions. Working paper, University of California, Irvine, CA.

Wallace, J. S. (1997). Adopting residual income-based compensation plans: Do you get what you pay for? The Journal of Accounting and Economics, 24, 275 - 300.

Weissenrieder, F. (1999). Economic Value Added or Cash Value Added. [Online] Available: http://www.anelda.com/articles/e3.html (Retrieved from January 20, 2000) 
Table 1. Some value-based measures in addition to $E V A$ : at a glance

\begin{tabular}{|c|c|c|}
\hline $\begin{array}{l}\text { Title of the value } \\
\text { based measure }\end{array}$ & Developed by & How to calculate? \\
\hline $\begin{array}{l}\text { Cash flow return on } \\
\text { investment }(C F R O I)\end{array}$ & $\begin{array}{c}\text { Boston } \\
\text { Consulting } \\
\text { Group }(B C G) \\
\text { and } H O L T \text { Value } \\
\text { Associates }\end{array}$ & $\begin{array}{l}\text { CFROI }\left(\frac{\text { Gross Cash Flow }}{\text { Gross Assets }}\right) \text {, is calculated in two steps. } \\
\text { First, inflation-adjusted cash flows are compared with the } \\
\text { inflation-adjusted gross investment. Then, the ratio of gross } \\
\text { cash flow to gross investment is translated into an internal } \\
\text { rate of return by recognizing the finite economic life of } \\
\text { depreciating assets and the residual value of non-depreciating } \\
\text { assets such as land and working capital (Myers, 1996). }\end{array}$ \\
\hline $\begin{array}{l}\text { Cash Value Added } \\
\qquad(C V A)\end{array}$ & Academicians & $\begin{array}{c}C V A=\text { Operating Cash Flow }(O C F) \text { - Operating Cash Flow } \\
\text { Demand }(O C F D) . O C F \text { is the sum of Earnings before } \\
\text { Depreciation, Interest and Tax (EBDIT, adjusted for } \\
\text { non-cash charges), working capital movement and } \\
\text { non-strategic investments. } O C F D \text { represents the average } \\
\text { capital costs per year (in absolute terms) that is constant over } \\
\text { the investment period. (Ottoson \& Weissenrieder, 1996) }\end{array}$ \\
\hline $\begin{array}{l}\text { Shareholder value } \\
\text { Added }(S V A)\end{array}$ & $\begin{array}{l}\text { Dr. Alfred } \\
\text { Rappaport and } \\
\text { LEK/Alcar } \\
\text { Consulting } \\
\text { Group }\end{array}$ & $\begin{array}{c}\text { Estimated future cash flows are discounted to present value } \\
\text { to calculate the value of the firm continuously. Measuring the } \\
\text { current performance is based on comparing these cash flow } \\
\text { estimates and period's real cash flow (Rappaport 1986, } \\
\text { p.183). }\end{array}$ \\
\hline $\begin{array}{l}\text { Adjusted Economic } \\
\text { Value Added }(A E V A)\end{array}$ & Academicians & $\begin{array}{l}\text { It is unlike to } E V A \text { in the sense that it uses current value of } \\
\text { assets instead of book values. }\end{array}$ \\
\hline $\begin{array}{c}\text { Refined Economic } \\
\text { Value Added }(R E V A)\end{array}$ & Academicians & $\begin{array}{l}\text { It uses the market value of the firm in the beginning of the } \\
\text { period instead of book value (Bacidore et al 1997, p.15). }\end{array}$ \\
\hline
\end{tabular}

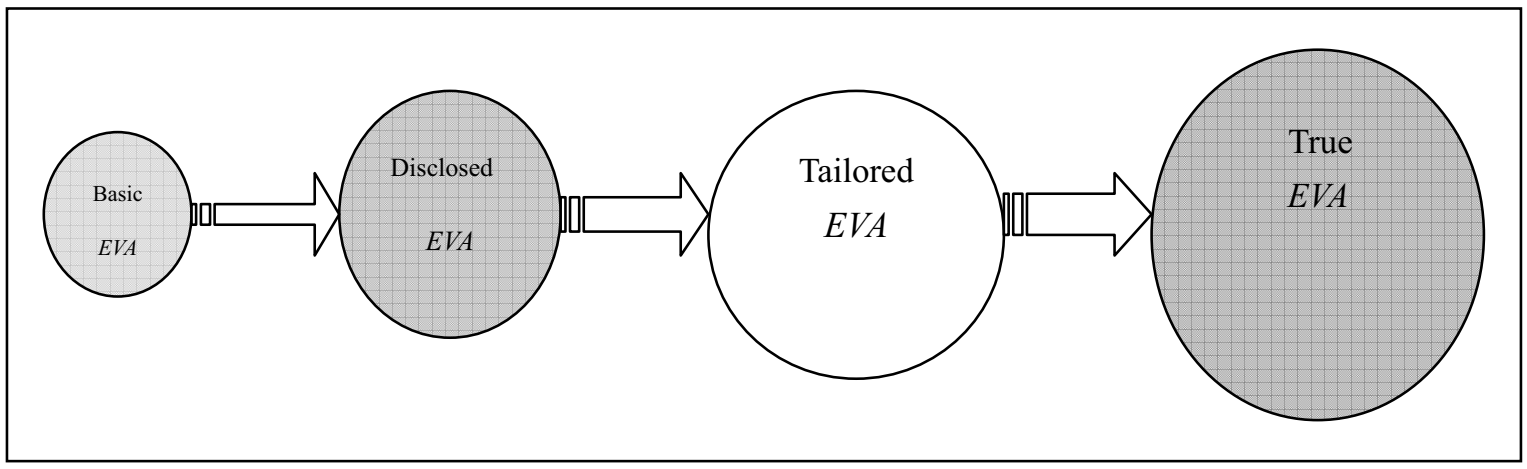

Figure 1. The EVA Spectrum (Hoque, Akter \& Shil, 2004, p. 139) 